\title{
AFLP Comparisons Among Claviceps africana Isolates from the United States, Mexico, Africa, Australia, India, and Japan
}

\author{
Paul W. Tooley, Erin D. Goley, and Marie M. Carras, USDA-ARS, Foreign Disease-Weed Science Research \\ Unit, 1301 Ditto Ave., Ft. Detrick, MD 21702-5023; and Nichole R. O’Neill, USDA-ARS, Molecular Plant Pathol- \\ ogy Laboratory, Beltsville, MD 20705
}

\begin{abstract}
Tooley, P. W., Goley, E. D., Carras, M. M., and O’Neill, N. R. 2002. AFLP comparisons among Claviceps africana isolates from the United States, Mexico, Africa, Australia, India, and Japan. Plant Dis. 86:1247-1252.

Eighty-seven isolates of the sorghum ergot pathogen, Claviceps africana, from diverse geographic locations were analyzed using four different amplified fragment length polymorphism (AFLP) primer combinations to determine genetic relationships among isolates. Most isolates showed unique AFLP haplotypes, indicating that substantial genetic variation is present within C. africana populations. Two major groupings of isolates were observable, with ca. $70 \%$ similarity between the two groups. One group consisted of Australian, Indian, and Japanese isolates and the other of U.S., Mexican, and African isolates. In spite of overall high levels of genetic diversity observed in C. africana, isolates within the two major groups were between 75 and $100 \%$ similar. The observed associations of $C$. africana isolates from worldwide sources could be the result of intercontinental trade and/or movement of seed. The data indicate that Africa was the likely source of $C$. africana that has become established in the Americas since 1996. Analysis of additional isolates in future studies will reveal whether these groupings are being maintained or whether population subdivision or reshuffling may occur.
\end{abstract}

Additional keywords: population genetics, Sphacelia sorghi, sugary disease

Sorghum ergot first appeared in the Western Hemisphere in Brazil in 1995 $(1,2,21)$, and by the end of the 1997 growing season it had spread to Mexico and the United States, reaching as far north as the state of Nebraska (11). Since then, sporadic outbreaks have occurred in the United States, with the disease spreading to additional states such as Georgia. While major devastating epidemics of sorghum ergot have generally not occurred in the United States since 1997, small outbreaks have occurred. Plant pathologists in sorghum-growing states have remained vigilant in monitoring the occurrence of ergot on volunteer sorghum and alternate hosts such as Johnson grass (Sorghum halepense). It is now widely believed that, in light of existing levels of inoculum observed on various host plants throughout states in which ergot is known to exist, the occurrence of environmental conditions that favor infection and disease development at the

Corresponding author: P. W. Tooley

E-mail: tooley@ncifcrf.gov

Accepted for publication 28 June 2002.

Publication no. D-2002-0821-01R

This article is in the public domain and not copyrightable. It may be freely reprinted with customary crediting of the source. The American Phytopathological Society, 2002. right time in the sorghum-growing season could result in damaging ergot epidemics.

Sorghum ergot is caused by three distinct Claviceps species (C. africana, $C$. sorghi, and C. sorghicola) which are differentiated based on morphology and other characters $(7,26)$. Molecular comparisons using sequences of $\beta$-tubulin and EF- $1 \alpha$ gene introns (24) have helped confirm the identity of the sorghum ergot pathogen present in the United States as C. africana, as distinct from other sorghum-infecting Claviceps species such as $C$. sorghi and $C$. sorghicola. In Japan (26) and India (2), two of the three sorghum-infecting Claviceps species coexist and may cause sorghum ergot in the same growing season.

Whether Claviceps species affecting sorghum can cross-hybridize in nature is not known, and sclerotia that give rise to the sexual stage of the pathogen have not been observed to germinate in nature. Currently, only a single species (C. africana) has been found in the United States causing sorghum ergot. However, global migrations such as the one that brought sorghum ergot to the Western Hemisphere in 1995 doubtless continue to occur through movement of sorghum seed and/or direct movement of conidia in wind currents and/or associated with insect or avian vectors. This could make it possible for additional species to enter and become established in the United States at any time.
In light of the ever-present potential for pathogen migration to occur and alter the composition of Claviceps species and genotypes in a particular region, it is important to document the genetic makeup of existing populations using the most reliable methods available. In particular, knowledge of levels of genotypic diversity is important in order to determine whether diversity is increasing due to influx of additional genotypes. With the potential for additional genetic diversity to be added to the U.S. population through future pathogen migrations, the likelihood of occurrence of new genotypes with enhanced pathogenic potential is increased. Sorghum breeders in states such as Texas and Kansas are attempting to incorporate ergot resistance into their breeding lines through screening and selection using existing pathogen genotypes. If new genotypes or pathogen species arrive in the United States, the more diverse pathogen population may render such resistance ineffective.

Knowledge of levels of pathogen diversity found elsewhere in the world can allow workers to better evaluate the epiphytotic potential of U.S. populations, as well as identify regions of the world where more stringent field screening of sorghum genotypes may be carried out. In a previous study, we used random amplified microsatellite (RAM) and amplified fragment length polymorphism (AFLP) analyses to characterize a small number of $C$. africana isolates from several continents; 20 isolates were analyzed using AFLPs with primers MseI+C and EcoRI+AG, and high levels of similarity were observed among isolates from the United States, Puerto Rico, and South Africa (25).

While the previous work allowed an initial look at genotypic diversity within $C$. africana, too few isolates were examined to give a clear overall picture of population relatedness on a global scale. The AFLP method detected intraspecific variation more readily than RAM (25) and was therefore the method of choice for this study. We have extended AFLP analysis to a larger group of isolates from worldwide sources and used three additional primer combinations to provide a deeper understanding of the genetic relationships among isolates from different geographic regions. The relationships and groupings we have identified among ergot strains from diverse continents provide basic knowledge about 
intercontinental populations of C. africana and will provide baseline data with which future population data may be compared. This will allow analysis of future migrations of $C$. africana and assessment of the degree to which levels of genetic variation may be shifting.

\section{MATERIALS AND METHODS}

Single conidial $C$. africana isolates were produced from ergot-infected sorghum provided by colleagues (Table 1). Cultures were established by diluting honeydew from infected sorghum seed heads ca. 100fold in sterile distilled water, then streaking them onto plates of $2 \%$ water agar containing $100 \mu \mathrm{g}$ of ampicillin and $100 \mu \mathrm{g}$ of streptomycin sulfate per $\mathrm{ml}$. Plates were incubated at $22^{\circ} \mathrm{C}$ in the dark, and individual germinated conidia were transferred to plates of potato dextrose agar (PDA) where they grew into colonies. When samples had low conidial viability, a conidial suspension was made in sterile distilled water and used to inoculate flowering heads of susceptible sorghum plants (male sterile line aTX 623 or aTX 2752, obtained from G. Odvody and D. Frederiksen, Texas A\&M University) grown in the USDA-ARS containment greenhouse complex at $\mathrm{Ft}$. Detrick, MD. Newly flowering sorghum heads were immersed in a conidial suspension made by combining several infected sorghum florets containing fresh or dried sphacelia and/or honeydew with $150 \mathrm{ml}$ of distilled water in a 1-qt plastic zipper-seal freezer bag. After gentle agitation, numerous conidia were released from the infected florets, making a dense conidial suspension. Following immersion in the suspension, heads were bagged with 1-qt plastic zipper-seal freezer bags for 24 to $48 \mathrm{~h}$ to preserve high relative humidity. Symptoms of infection and initial honeydew production could be observed on inoculated heads 5 to 7 days after removal of the bags. Fresh honeydew produced on inoculated heads was then used to establish single-conidial cultures as described above.

DNA was extracted from 5 to $10 \mathrm{mg}$ of lyophilized C. africana mycelium grown at $22^{\circ} \mathrm{C}$ in the dark in yeast-malt extract (YM) broth (Difco Laboratories, Detroit,

Table 1. Sources of the 87 Claviceps africana isolates used in this study ${ }^{\mathrm{a}}$

\begin{tabular}{|c|c|c|c|c|c|}
\hline $\begin{array}{l}\text { Species and } \\
\text { isolate }^{\mathrm{b}}\end{array}$ & Geographic source & $\begin{array}{c}\text { Year of } \\
\text { isolation }\end{array}$ & $\begin{array}{l}\text { Species and } \\
\text { isolate }\end{array}$ & Geographic source & $\begin{array}{c}\text { Year of } \\
\text { isolation }\end{array}$ \\
\hline Cls-1 & Patancheru, India & 1997 & Cla-83 & Miyakonojo, Japan & 1988 \\
\hline Cls-2 & Akola, India & 1997 & Cla- 88 & Miyakonojo, Japan & 1990 \\
\hline Cls-3 & Dharwar, India & 1997 & Cla-89 & Lusaka, Zambia $^{\mathrm{c}}$ & 1999 \\
\hline Cls-4 & Patancheru, India & 1997 & Cla-91 & Roma, Queensland, Australia & 1999 \\
\hline Cla-1 & Norwin, Queensland, Australia & 1996 & Cla-92 & Oakey, Queensland, Australia & 1999 \\
\hline Cla-2 & Norwin, Queensland, Australia & 1996 & Cla-93 & Queensland, Australia & 1997 \\
\hline Cla-3 & Monto, Queensland, Australia & 1997 & Cla-94 & Capella, Queensland, Australia & 1999 \\
\hline Cla-4 & College Station, Texas, USA & 1997 & Cla-95 & Warwick, Queensland, Australia & 1999 \\
\hline Cla-5 & College Station, Texas, USA & 1997 & Cla-96 & Roma, Queensland, Australia & 1999 \\
\hline Cla-7 & Isabela, Puerto Rico & 1997 & Cla-97 & Emerald, Queensland, Australia & 1999 \\
\hline Cla-8 & Isabela, Puerto Rico & 1997 & Cla-99 & Sinton, Texas, USA & 1999 \\
\hline Cla-9 & Weslaco, Texas, USA & 1998 & Cla-100 & Sinton, Texas, USA & 1999 \\
\hline Cla-10 & Weslaco, Texas, USA & 1998 & Cla-101 & Sinton, Texas, USA & 1999 \\
\hline Cla-12 & Isabela, Puerto Rico & 1998 & Cla-102 & Kiowa County, Kansas, USA & 1997 \\
\hline Cla-14 & Isabela, Puerto Rico & 1998 & Cla-103 & Kiowa County, Kansas, USA & 1997 \\
\hline Cla-17 & Isabela, Puerto Rico & 1998 & Cla-104 & Kiowa County, Kansas, USA & 1997 \\
\hline Cla-25 & Isabela, Puerto Rico & 1998 & Cla-105 & Allen County, Kansas, USA & 1997 \\
\hline Cla-32 & Guayanilla, Puerto Rico & 1998 & Cla-107 & Allen County, Kansas, USA & 1997 \\
\hline Cla-34 & Guayanilla, Puerto Rico & 1998 & Cla-111 & Isabela, Puerto Rico & 1999 \\
\hline Cla-38 & Virginia, Nebraska, USA & 1997 & Cla-112 & Isabela, Puerto Rico & 1999 \\
\hline Cla-42 & Virginia, Nebraska, USA & 1997 & Cla-114 & Nazareth, Texas, USA & 1999 \\
\hline Cla-46 & Grantham, Queensland, Australia & 1997 & Cla-116 & Nazareth, Texas, USA & 1999 \\
\hline Cla-47 & Mutdapilly, Queensland, Australia & 1997 & Cla-117 & Lusaka, Zambia ${ }^{c}$ & 1999 \\
\hline Cla-48 & Gindie, Queensland, Australia & 1997 & Cla-120 & Harare, Zimbabwe & 1999 \\
\hline Cla-49 & Hale Center, Texas, USA & 1998 & Cla-121 & Harare, Zimbabwe & 1999 \\
\hline Cla-51 & Vega, Texas, USA & 1998 & Cla-122 & Bulawayo, Zimbabwe & 1999 \\
\hline Cla -52 & Corpus Christi, Texas, USA & 1998 & Cla-123 & Lusaka, Zambia $^{\mathrm{c}}$ & 1999 \\
\hline Cla-53 & Corpus Christi, Texas, USA & 1998 & Cla-124 & Lusaka, Zambia ${ }^{c}$ & 1999 \\
\hline Cla-54 & Corpus Christi, Texas, USA & 1998 & Cla-128 & Panmure, Zimbabwe & 1999 \\
\hline Cla-56 & Potchefstroom, South Africa & 1998 & Cla-129 & Ft. Pierce, Florida, USA & 1999 \\
\hline Cla-59 & Ennis, Texas, USA & 1998 & Cla-130 & Ft. Pierce, Florida, USA & 1999 \\
\hline Cla-60 & Ennis, Texas, USA & 1998 & Cla-133 & Ft. Pierce, Florida, USA & 1999 \\
\hline Cla-61 & Ennis, Texas, USA & 1998 & Cla-134 & Ft. Pierce, Florida, USA & 1999 \\
\hline Cla-62 & Comonfort, Mexico & 1998 & Cla-135 & Nazareth, Texas, USA & 1999 \\
\hline Cla-63 & Comonfort, Mexico & 1998 & Cla-137 & Nazareth, Texas, USA & 1999 \\
\hline Cla-66 & Celaya, Mexico & 1998 & Cla-138 & Seek, Kansas & 1999 \\
\hline Cla-68 & Comonfort, Mexico & 1998 & Cla-142 & Keesee, Kansas & 1999 \\
\hline Cla-69 & Cortazu, Mexico & 1998 & Cla-143 & Kiowa County, Kansas, USA & 1997 \\
\hline Cla-70 & Tifton, Georgia, USA & 1998 & Cla-IN-1 & Patancheru, India & 1999 \\
\hline Cla-74 & Tifton, Georgia, USA & 1998 & Cla-IN-2 & Maachinenapally, India & 1999 \\
\hline Cla-77 & Tifton, Georgia, USA & 1998 & Cla-IN-7 & Chakalisherupally, India & 1999 \\
\hline Cla-78 & Ennis, Texas, USA & 1998 & Cla-IN-8 & Injamura, India & 1999 \\
\hline Cla-79 & Ennis, Texas, USA & 1998 & Cla-IN-29 & Mana, India & 1999 \\
\hline Cla-80 & Miyakonojo, Japan & 1988 & & & \\
\hline
\end{tabular}

a Sorghum bicolor was the host for all C. africana isolates listed except for Cla-1 and Cla-2, whose host was forage sorghum (Sorghum sp.), and Cla-68, whose host was Johnson grass (Sorghum halepense).

${ }^{b}$ Pure cultures of isolates Cls- 1 to Cls- 4 and Cla-IN-1, $-2,-7,-8$, and -29 were provided by R. Bandyopadhyay, ICRISAT, Patancheru, India, and pure cultures of isolates Cla-2 and Cla-3 were provided by Malcolm Ryley, Queensland Dept. of Primary Industries, Australia. Pure cultures of Cla-91 through Cla-97 were obtained from Birte Komolong, University of Queensland, Australia. All other cultures were established from single conidia in our containment laboratory as described in Materials and Methods.

${ }^{c}$ Sample from which isolate was obtained was collected at the Golden Valley Research Farm, 25 miles north of Lusaka, Zambia, by G. Odvody and N. McLaren. 
MI) using a modified CTAB DNA extraction protocol (23). AFLPs were generated with the AFLP Analysis System II (Invitrogen, Carlsbad, CA) using a method previously described by Tooley et al. (25). Primer sets used for analysis in the selective amplification included $\mathrm{Mse}+\mathrm{I} \mathrm{C}$ combined with EcoRI+AG, EcoRI+AC, EcoRI+TA, and EcoRI+TT. Data were combined for the analysis. Initially, two additional primer combinations were used (Mse I+C combined with EcoRI+AA and EcoRI+AT), but observed levels of polymorphism among isolates were very low and the data were not included in the analysis.

AFLP profiles were manually scored for presence or absence of bands and entered into a binary matrix. Only polymorphisms that could be scored unequivocally for presence or absence of bands were included in the analyses; faint bands were never scored as absent. Bands were assumed to be independent. Binary matrices were analyzed to obtain simple matching coefficients among the isolates using NTSYS-pc, version 2.0 (Exeter Software, Setauken, NY). Simple matching coefficients were clustered to generate similarity trees using SAHN clustering using the unweighted pair-group method with arithmetic average (UPGMA) algorithm in NTSYS-pc. Claviceps purpurea was used as an outgroup species, since it represents on biological grounds a related species that is less closely related to each of the taxa under consideration (isolates of $C$. africana) than any are to one other $(24,25)$.

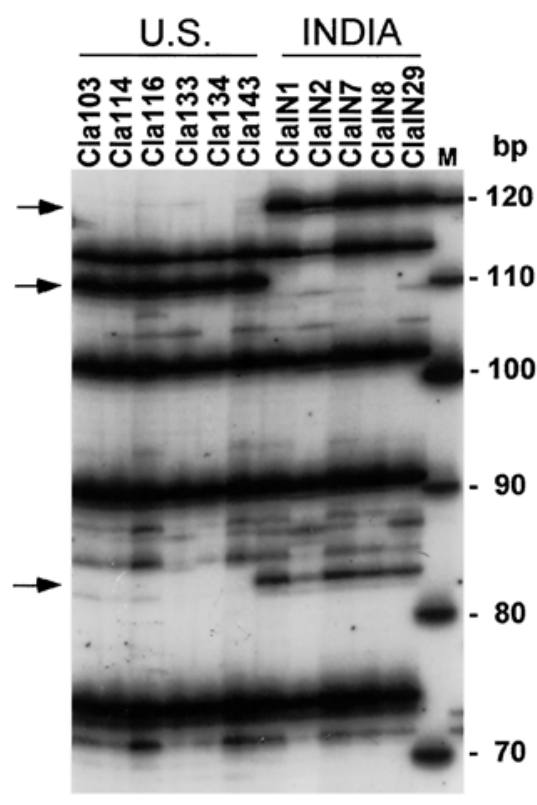

Fig. 1. Section of autoradiograph (primer EcoRI+AG) showing amplified fragment length polymorphism (AFLP) differences between U.S. and Indian isolates of Claviceps africana. Arrows represent bands present in U.S. isolates and absent in Indian isolates (111 bp) or vice versa (120 bp, $83 \mathrm{bp}$ ).
Measures of genetic variability for isolates within and among regions were calculated using POPGENE (34) and tools for population genetic analysis (TFPGA) (17), which are Windows-based freeware programs for the analysis of population genetic data. Genetic diversity within each $C$. africana population was assessed by using the above programs to calculate the observed and effective number of alleles (13), Nei's gene diversity (18), the Shannon information index (22), the estimated (unbiased) average heterozygosity (18), and the proportion of polymorphic loci (9).

Analysis of molecular variance (AMOVA) was performed as described by Excoffier et al. (5) using the program Genetic Studio 2.0 (4) and using the methods of Weir and Cockerham (30). AMOVA produces estimates of variance components and $F$ statistic analogs ( $\Phi$ statistics) that reflect genetic diversity at different levels of hierarchical subdivision. It was developed to estimate and evaluate variance components of genetic markers within and between populations, and has been used previously to assess genetic relatedness in plant-pathogenic fungi $(21,29,31)$ as well as in plants (10). The fixation index (or $F$ statistic analog) calculated in AMOVA is equivalent to the reduction in heterozygosity expected with random mating at any one level of population hierarchy relative to another more inclusive level of the hierarchy (33). The genetic distance between any two populations is represented by its $\Phi_{\text {st }}$ value, which equals the proportion of the total variance that is partitioned between the two populations (5).

\section{RESULTS}

A total of 130 loci were scored for the four AFLP primer combinations used; 35 loci were scored for primer set $\mathrm{Mse}+\mathrm{I} /$ EcoRI+AG, 30 loci for $\mathrm{Mse}+\mathrm{I} / \mathrm{C} /$ EcoRI+AC, 36 loci for Mse I+C/ $E c o R I+T A$, and 29 loci for $M s e I+C /$ EcoRI+TT. Figure 1 shows AFLP results for primer set $M s e \mathrm{I}+\mathrm{C} / E c o \mathrm{RI}+\mathrm{AG}$, showing some prominent differences between U.S. and Indian isolates. Primer sets varied in percentage of polymorphic loci, gene diversity, and Shannon Index, with primer TT the lowest (Table 2). Primer TA showed the highest gene diversity and percentage of polymorphic loci.

The total number of AFLP bands observed over all four primer combinations varied little among isolate groups, ranging from 98 bands for African isolates to 105 bands for U.S. isolates (Table 3). However, nearly every isolate examined was unique in terms of its AFLP haplotype, indicating a high degree of overall genetic diversity within $C$. africana (Table 3). Genetic diversity in terms of percent polymorphic loci was lowest for Japanese isolates (10\%) and highest for U.S. (45.4\%) and African $(43.8 \%)$ isolates (Table 3 ).

When a dendrogram was constructed from the combined AFLP data from all four primer combinations, two major groupings were observable. One group consisted of Australian, Indian, and Japanese isolates, and the other consisted of U.S., Mexican, and African isolates, with ca. $70 \%$ similarity between the groups (Fig. 2). Isolates within groups ranged from ca. 75 to $100 \%$ similar. Outgroup $C$.

Table 2. Gene diversity measures for four amplified fragment length polymorphism (AFLP) primer pair combinations used to analyze Claviceps africana from worldwide sources

\begin{tabular}{lccccc}
\hline Primer pair $^{\mathbf{a}}$ & $\mathbf{n a}^{\mathbf{b}}$ & $\mathbf{n e}^{\mathbf{c}}$ & $\mathbf{h}^{\mathbf{d}}$ & $\mathbf{I}$ & $\mathbf{p p l}(\boldsymbol{\%})^{\mathbf{f}}$ \\
\hline AG & 1.7222 & 1.3383 & 0.1983 & 0.3013 & 72.2 \\
AC & 1.7667 & 1.3674 & 0.2090 & 0.3139 & 76.7 \\
TA & 1.8611 & 1.5076 & 0.2872 & 0.4237 & 86.1 \\
TT & 1.4828 & 1.2988 & 0.1726 & 0.2537 & 48.3 \\
Combined & 1.3130 & 1.2099 & 0.1180 & 0.1740 & 71.8 \\
\hline
\end{tabular}

a AFLP primer pairs were $M s e \mathrm{I}+\mathrm{C}$ paired with, respectively, EcoRI+AG, EcoRI+AC, EcoRI+TA, and EcoRI+TT.

${ }^{\mathrm{b}}$ Observed number of alleles.

${ }^{\mathrm{c}}$ Effective number of alleles, which is the reciprocal of homozygosity (13).

${ }^{\mathrm{d}}$ Nei's gene diversity (18).

e Shannon's information index as a measure of gene diversity (22).

${ }^{\mathrm{f}}$ Percentage of polymorphic loci (34).

Table 3. Estimates of genetic diversity within groups of Claviceps africana from different geographic regions $^{\mathrm{a}}$

\begin{tabular}{lcccc}
\hline $\begin{array}{l}\text { Geographic } \\
\text { source }\end{array}$ & Isolates & $\begin{array}{c}\text { Unique } \\
\text { haplotypes }\end{array}$ & $\begin{array}{c}\text { Total AFLP } \\
\text { bands }\end{array}$ & $\begin{array}{c}\text { Polymorphic } \\
\text { loci (\%) }\end{array}$ \\
\hline India & 9 & 8 & 101 & 31.5 \\
Australia & 13 & 12 & 100 & 38.5 \\
Japan & 3 & 3 & 99 & 10.0 \\
U.S. & 48 & 47 & 105 & 45.4 \\
Africa & 9 & 9 & 98 & 43.8 \\
Mexico & 5 & 5 & 102 & 35.4 \\
\hline
\end{tabular}

${ }^{\text {a }}$ Data are combined from four amplified fragment length polymorphism (AFLP) primer pair combinations representing 130 total loci. 
purpurea isolate Clp-1 (ATCC 34699, Montana, USA, host Hordeum vulgare) showed ca. $30 \%$ similarity with $C$. africana isolates (data not shown). Table 4 and
Figure 3 show genetic similarity and Nei's genetic distance among six geographic collections of $C$. africana. Distances ranged from ca. 0.04 for the most closely
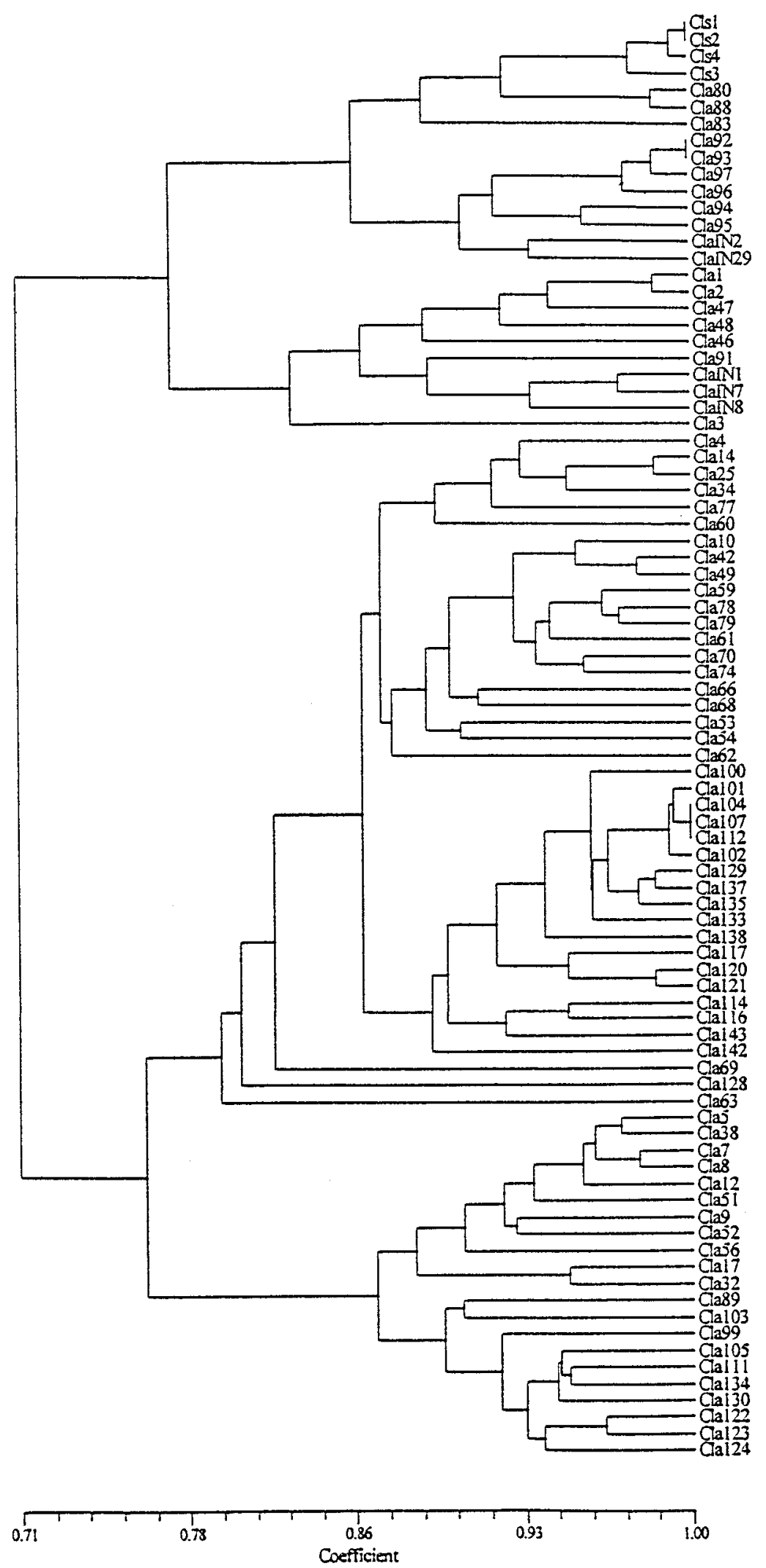

Fig. 2. Dendrogram showing similarities among isolates of Claviceps africana based on amplified fragment length polymorphism (AFLP) analysis (data from four primer combinations combined) using simple matching coefficients. The tree was generated using the SAHN clustering program with the unweighted pair-group method with arithmetic average (UPGMA) algorithm in NTSYS-pc, version 2.0.

related groups to ca. 0.20 for the most distantly related groups. U.S. and African isolates were the most closely related, followed by Indian and Australian isolates. Japanese and African isolates were the most distantly related (Table 4, Fig. 3).

Hierarchical AMOVA was conducted for the combined AFLP data based on groups (United States/Africa/Mexico versus India/Australia/Japan) and collections within groups (United States, Africa, and Mexico within the first group and India, Australia, and Japan within the second group) (Table 5) identified from dendrograms (Fig. 2). Most of the AFLP haplotype genetic diversity $(50.2 \%)$ was found within each collection, but a large amount (38.5\%) also separated groups. The differences among collections within groups are relatively small $(11.4 \%)$. The $\Phi$ statistic also reflected these trends (Table 5).

Pairwise comparisons of $\Phi_{\text {st }}$ values between collections of $C$. africana from six different regions (Table 6) show that the six populations were all significantly different from one another (at the 5\% level), with the exception of Africa-Mexico and United States-Mexico. United StatesAfrica were different from one another, even though their genetic differentiation was low $\left(\Phi_{\text {st }}=0.137\right)$.

\section{DISCUSSION}

We used AFLP markers to analyze the genetic diversity among 87 isolates of the sorghum ergot pathogen, C. africana, from global sources. We found a high level of genetic diversity in all groups analyzed, with almost as many unique AFLP genotypes as isolates. Most of the AFLP haplotype genetic diversity was found within collections made in individual countries, but a large amount also separated the major geographical groups (United States/Africa/ Mexico versus India/Australia/Japan). The differences among collections (countries) within the major geographical groups are relatively small. Wright (33) suggested that fixation indices (analogous to the $\Phi$ values in Table 5) ranging from 0.15 to 0.25 indicate great genetic differentiation, while values above 0.25 indicate very great genetic differentiation. Thus, we consider that the $C$. africana we sampled and analyzed shows very high levels of genetic differentiation.

In terms of AFLP analysis, we observed major associations of Indian, Australian, and Japanese isolates, and U.S., Mexican, and African isolates. Major groupings shared ca. $70 \%$ similarity, while within groups, isolates ranged from 75 to $100 \%$ similar. These associations support the results of other workers (20), who found similar associations of isolates based on random amplified polymorphic DNA (RAPD) analysis. They also support the results of our previous study (25), which examined AFLP variation in a smaller geographical representation of isolates. 
A limitation of our study was the low number of isolates collected from Japan and Mexico. Numbers collected from these locations were too low to have high confidence in diversity measures, pointing to the need for analysis of additional isolates from these locations in the future.

Langdon (16) believed that ecological and physiological adaptation were key processes involved in differentiation of Claviceps species. Genetic mechanisms which could explain such diversity include simple mutation, mitotic recombination, heterokaryosis, parasexual and/or sexual recombination (6), as well as more recently recognized genetic mechanisms such as chromosomal polymorphism, the presence of accessory chromosomes, cytoplasmically transmitted elements, and transposons (14). For the most studied Claviceps species, C. purpurea, a high degree of heterokaryosis observed among field isolates was theorized by Tudzynski (27) to be due to a high mutation rate. Also in C. purpurea, parasexual processes have been induced (3) and mitochondrial plasmids observed (28). White et al. (32) theorized that $C$. purpurea would have ample opportunity for genetic exchange because of the presence of the "honeydew stage" in which conidia are exposed to insects that visit florets, allowing mixing of sphacelial conidia from different populations and subsequent parasexual recombination. Similar mechanisms could occur with $C$. africana, as it also contains a honeydew stage.

Greater knowledge of the role of the sexual cycle, and whether it occurs in areas of recent introduction such as the United States, could shed light on the pathogen's propensity to generate novel genetic variation, which may complicate the deployment of effective long-term control measures. To date, sclerotia, which give rise to the sexual stage of the fungus, have not been observed in the United States, and it has been theorized that U.S. environmental conditions do not favor sclerotial formation. However, even with no evidence of the presence of an active sexual stage, $C$. africana genotypes appear to be highly diverse, as evidenced by the high numbers of unique AFLP genotypes observed in all populations. These results seem to agree with those observed for 29 C. purpurea isolates assayed using RAPD markers, in which high numbers of unique RAPD profiles were obtained (12).

The practical implications of our AFLP results include the finding of substantial genetic diversity within U.S. C. africana populations, facilitating the development of races or strains in the future. The diversity is surprising, given the very recent introduction of $C$. africana into the United States, and indicates that genetic mechanisms exist in C. africana to generate substantial variation in the absence of an active sexual stage.
The geographic associations of $C$. africana isolates observed from AFLP and RAPD analysis are reasonable in terms of the seed trade among the various countries

and continents. Australia, India, and Japan are linked as trading partners, as are the United States and Mexico. Based on RAPD analysis, Pažoutová (20) suggested

Table 4. Nei's unbiased measures of genetic identity and genetic distance ${ }^{a}$ for Claviceps africana amplified fragment length polymorphism (AFLP) data based on four primer combinations

\begin{tabular}{lcccccc}
\hline & \multicolumn{6}{c}{ Population } \\
\cline { 2 - 7 } Population & India & Australia & U.S. & Africa & Mexico & Japan \\
\hline India & $\ldots$ & 0.9654 & 0.8242 & 0.8228 & 0.8259 & 0.9146 \\
Australia & 0.0352 & $\ldots$ & 0.8478 & 0.8640 & 0.8327 & 0.8556 \\
U.S. & 0.1934 & 0.1651 & $\ldots$ & 0.9666 & 0.9619 & 0.7906 \\
Africa & 0.1951 & 0.1461 & 0.0340 & $\ldots$ & 0.9187 & 0.7809 \\
Mexico & 0.1913 & 0.1830 & 0.0388 & 0.0848 & $\ldots$ & 0.8214 \\
Japan & 0.0893 & 0.1560 & 0.2349 & 0.2474 & 0.1967 & $\ldots$ \\
\hline
\end{tabular}

a Nei's genetic identity (above diagonal) and genetic distance (below diagonal) (18).

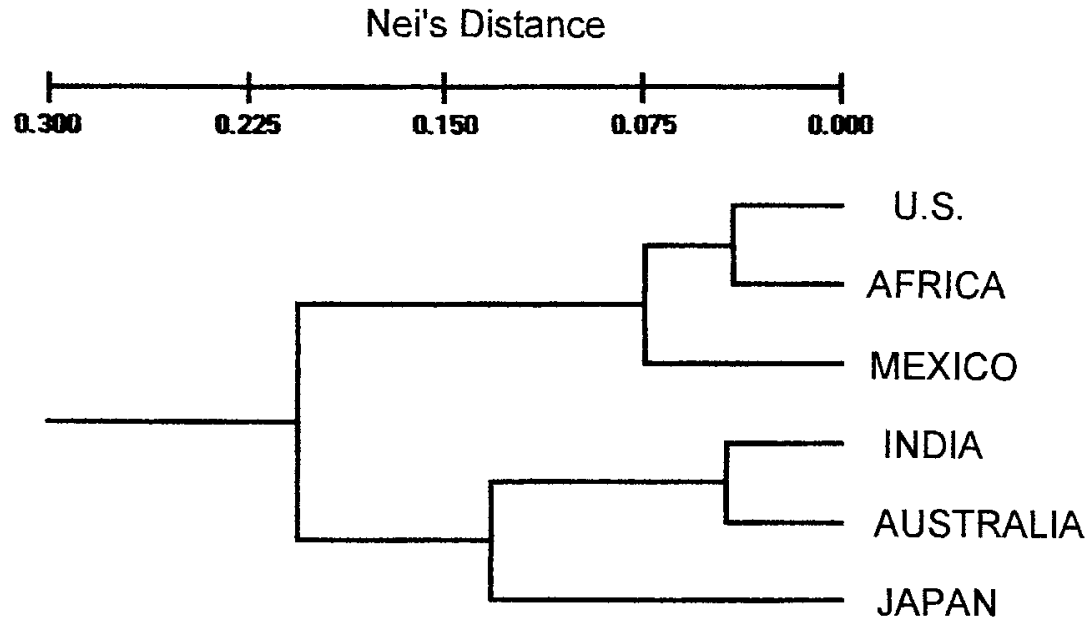

Fig. 3. Graphical representation of genetic distance relationships among six collections of Claviceps africana isolates from different geographic regions.

Table 5. Analysis of molecular variance (AMOVA) table for groups and collections of Claviceps africana from different geographic regions

\begin{tabular}{lrrrrrrr}
\hline & df & \multicolumn{1}{c}{$\mathbf{S S}^{\mathbf{a}}$} & $\mathbf{M S}^{\mathbf{b}}$ & $\boldsymbol{\sigma}^{\mathbf{c}}$ & $\boldsymbol{\%}^{\mathbf{d}}$ & $\boldsymbol{\Phi}^{\mathbf{e}}$ & $\boldsymbol{P}_{\text {value }^{\mathbf{f}}}$ \\
\hline Among groups & 2 & 226.417 & 113.209 & 4.957 & 38.5 & 0.385 & 0.010 \\
Among coll. (groups) & 4 & 81.064 & 20.266 & 1.462 & 11.4 & 0.185 & 0.010 \\
Within collections & 81 & 523.110 & 6.46 & 6.458 & 50.2 & 0.498 & 0.010 \\
Total & 87 & 830.591 & & 12.877 & & & \\
\hline
\end{tabular}

a Sum of squares.

${ }^{\mathrm{b}}$ Mean square.

c Variance component.

${ }^{\mathrm{d}}$ Percentage of total haplotype amplified fragment length polymorphism (AFLP) diversity present among groups, among populations within groups, and within populations.

${ }^{\mathrm{e}} \Phi$ statistic as described by Excoffier et al. (5).

${ }^{\mathrm{f}}$ Probability of having a more extreme $\Phi$ statistic than the observed values by chance alone.

Table 6. Pairwise $\Phi_{\mathrm{st}}$ values $^{\mathrm{a}}$ between six collections of Claviceps africana (above the diagonal) and their probability $P$ values ${ }^{\mathrm{b}}$ (below the diagonal)

\begin{tabular}{llccccc}
\hline Collection & Africa & Mexico & U.S. & Japan & Australia & India \\
\hline Africa & 0 & 0.147 & 0.137 & 0.536 & 0.377 & 0.466 \\
Mexico & 0.091 & 0 & 0.114 & 0.499 & 0.395 & 0.456 \\
U.S. & $<0.001$ & 0.061 & 0 & 0.580 & 0.467 & 0.521 \\
Japan & $<0.001$ & 0.010 & $<0.001$ & 0 & 0.447 & 0.341 \\
Australia & $<0.001$ & $<0.001$ & $<0.001$ & $<0.001$ & 0 & 0.156 \\
India & $<0.001$ & $<0.001$ & $<0.001$ & $<0.001$ & $<0.001$ & 0 \\
\hline
\end{tabular}

${ }^{\text {a }} F$ statistic analog (5).

${ }^{b}$ Probability that a random distance calculated by analysis of molecular variance (AMOVA) with 1,000 permutations is greater than the observed distance, $\Phi_{\mathrm{st}}$. 
that India or a Southeast Asian country such as Thailand may have been the likely origin of ergot introduction into Australia and also suggested that Africa is the source of $C$. africana introduction into the Americas. Our data from AFLP analysis lends weight to the hypothesis that Africa may have been the source of $C$. africana that reached South America in 1996 and the United States in 1997 via the seed trade or other mechanism.

The stability of isolate groupings we observed from AFLP analysis is not known. Recent evidence from studies of Australian C. africana using radiolabeled amplified fragment (RAF) analysis indicates that genetic diversity may be increasing in some populations since the collection of our isolates. Komolong et al. (15) showed a higher level of recent genetic diversity than found in original populations. Perhaps movement of the pathogen from other regions either directly or via the sorghum seed trade is an ongoing process that has contributed to an increase in diversity in Australian C. africana populations.

Further analysis of greater numbers of C. africana isolates from diverse regions including Africa, India, Australia, South and Central America, and the United States will help determine the potential source of sorghum ergot in the United States and provide more data for assessing levels of genotypic diversity in this rapidly emerging pathogen. Greater sampling of isolates from Southeast Asian countries would be desirable to determine their similarity with Indian and Australian isolates. More detailed analysis of populations within India and Africa would also be desirable, as these are considered the regions in which C. africana has evolved for the longest period of time. Finally, other molecular tools such as microsatellites (19), dispersed repetitive DNA sequences (8), and/or transposon analysis (29) could be used to validate findings from AFLP analysis.

\section{ACKNOWLEDGMENTS}

We thank the colleagues who provided infected sorghum or pure cultures of $C$. africana for these studies, including Ranajit Bandyopadhyay, Sukumar Chakrobotry, Larry Claflin, Jeffrey Dahlberg, Richard Frederiksen, Tom Isakeit, Stanley Jensen, Birte Komolong, Neal McClaren, Gary Odvody, Malcolm Ryley, and Takao Tsukiboshi. Thanks also to S. Pažoutová for critical reading of the manuscript and many helpful suggestions.

\section{LITERATURE CITED}

1. Bandyopadhyay, R., Frederickson, D. E., McLaren, N. W., and Odvody, G. N. 1996.
Ergot-A global threat to sorghum. Int. Sorghum Millet Newsl. 37:1-32.

2. Bandyopadhyay, R., Frederickson, D. E., McLaren, N. W., Odvody, G. N., and Ryley, M. J. 1998. Ergot: A new disease threat to sorghum in the Americas and Australia. Plant Dis. 82:356-367.

3. Brauer, K. L., and Robbers, J. E. 1987. Induced parasexual processes in Claviceps sp. strain SD58. Appl. Environ. Microbiol. 53:7073.

4. Dyer, R. 1998. Genetic Studio 2.0. Shareware. Rodney Dyer, Dept. of Botany, Iowa State University, Ames.

5. Excoffier, L., Smouse, P. E., and Quattro, J. M. 1992. Analysis of molecular variance inferred from metric distances among DNA haplotypes: Application to human mitochondrial DNA restriction data. Genetics 131:479491.

6. Fincham, J. R. S., Day, P. R., and Radford, A. 1979. Fungal Genetics. University of California, Los Angeles.

7. Frederickson, D. E., Mantle, P. G., and DeMilliano, W. A. J. 1991. Claviceps africana sp. nov.; the distinctive ergot pathogen of sorghum in Africa. Mycol. Res. 95:1101-1107.

8. Hamer, J. E., Farrall, L., Orbach, M. J., Valent, B., and Chumley, F. G. 1989. Host species-specific conservation of a family of repeated DNA sequences in the genome of a fungal plant pathogen. Proc. Natl. Acad. Sci. USA 86:9981-9985.

9. Hartl, D. L., and Clark, A. G. 1997. Principles of Population Genetics. Sinauer Associates Inc., Sunderland, MA.

10. Huff, D. R., Peakall, R., and Smouse, P. E. 1993. RAPD variation within and among natural populations of outcrossing buffalograss [Buchloe dactyoloides (Nutt.) Engelm.]. Theor. Appl. Genet. 86:927-934.

11. Isakeit, T., Odvody, G. N., and Shelby, R. A. 1998. First report of sorghum ergot caused by Claviceps africana in the United States. Plant Dis. 82:592.

12. Jungehülsing, U., and Tudzynski, P. 1997. Analysis of genetic diversity in Claviceps purpurea by RAPD. Mycol. Res. 101:1-6.

13. Kimura, M., and Crow, J. F. 1964. The number of alleles that can be maintained in a finite population. Genetics 49:725-738.

14. Kistler, H. C., and Miao, V. P. W. 1992. New modes of genetic change in filamentous fungi. Annu. Rev. Phytopathol. 30:131-152.

15. Komolong, B., Chakraborty, S., Ryley, M., and Yates, D. 2001. Genetic diversity of Claviceps africana in Australia. (Abstr.) Phytopathology 91:S50.

16. Langdon, R. F. N. 1954. The origin and differentiation of Claviceps species. Trans. Br. Mycol. Soc. 47:205-213.

17. Miller, M. P. 1997. Tools for population genetic analyses (TFPGA) 1.3: A Windows program for the analysis of allozyme and molecular population genetic data. Computer software. Mark P. Miller, Dept. of Fisheries and Wildlife, Utah State University, Logan.

18. Nei, M. 1978. Estimation of average heterozygosity and genetic distance from a small number of individuals. Genetics 89:583-590.

19. Neu, C., Kaemmer, D., Kahl, G., Fischer, D., and Weising, K. 1999. Polymorphic microsatellite markers for the banana pathogen $M y$ cosphaerella fijiensis. Mol. Ecol. 8:513-525.

20. Pažoutová, S., Bandyopadhyay, R., Frederickson, D. E., Mantle, P. G., and Frederiksen, R. A. 2000. Relations among sorghum ergot isolates from the Americas, Africa, India, and Australia. Plant Dis. 84:437-442.

21. Pimentel, G., Peever, T. L., and Carris, L. M. 2000. Genetic variation among natural populations of Tilletia controversa and T. bromi. Phytopathology 90:376-383.

22. Shannon, C. E., and Weaver, W. 1949. The Mathematical Theory of Communication. University of Illinois, Urbana.

23. Taylor, B. H., and Powell, A. 1982. Isolation of plant DNA and RNA. Focus 4:4-6.

24. Tooley, P. W., Goley, E. D., Carras, M. M., Frederick, R. D., and Weber, E. L. 2001 Characterization of Claviceps species pathogenic on sorghum by sequence analysis of the $\beta$-tubulin gene intron 3 region and EF- $1 \alpha$ gene intron 4. Mycologia 93:541-551.

25. Tooley, P. W., O'Neill, N. R., Goley, E. D., and Carras, M. M. 2000. Assessment of diversity in Claviceps africana and other Claviceps species by RAM and AFLP analyses. Phytopathology 90:1126-1130.

26. Tsukiboshi, T., Shimanuki, T., and Uematsu, T. 1999. Claviceps sorghicola sp. nov., a destructive ergot pathogen of sorghum in Japan. Mycol. Res. 103:1403-1408.

27. Tudzynski, P. 1999. Genetics of Claviceps purpurea. Pages 79-93 in: Ergot: The Genus Claviceps. V. Kren and L. Cvak, eds. Harwood Academic Publishers, Amsterdam.

28. Tudzynski, P., Dubell, A., and Esser, K. 1983. Extrachromosomal genetics of Claviceps purpurea. I. Mitochondrial DNA and mitochondrial plasmids. Curr. Genet. 7:145-150.

29. Viji, G., Wu, B., Kang, S., Uddin, W., and Huff, D. R. 2001. Pyricularia grisea causing gray leaf spot of perennial ryegrass turf: Population structure and host specificity. Plant Dis. 85:817-826.

30. Weir, B. S., and Cockerham, C. C. 1984 Estimating F-statistics for the analysis of population structure. Evolution 38:13581370.

31. Weir, T. L., Huff, D. R., Christ, B. J., and Romaine, C. P. 1998. RAPD-PCR analysis of genetic variation among isolates of Alternaria solani and Alternaria alternata from potato and tomato. Mycologia 90:813-821.

32. White, J. F., Jr., Sullivan, R., Moy, M., Patel, R., and Duncan, R. 2000. An overview of problems in the classification of plantparasitic Clavicipitaceae. Studies in Mycology No. 45:95-105.

33. Wright, S. 1978. Evolution and the Genetics of Populations. University of Chicago, Chicago.

34. Yeh, F. C., Yang, R.-C., Boyle, T. B. J., Ye, Z H., and Mao, J. X. 1997. POPGENE, the userfriendly shareware for population genetic analysis. Molecular Biology and Biotechnology Centre, University of Alberta, Canada. 